\title{
Globalisation of tobacco industry influence and new global responses
}

\author{
Derek Yach, Douglas Bettcher
}

\begin{abstract}
The globalisation of tobacco marketing, trade, research, and industry influence represents a major threat to public health worldwide. Drawing upon tobacco industry strategy documents prepared over several decades, this paper will demonstrate how the tobacco industry operates as a global force, regarding the world as its operating market by planning, developing, and marketing its products on a global scale. The industry has used a wide range of methods to buy influence and power, and penetrate markets across the world. It has an annual turnover of almost US $\$ 400$ billion. In contrast, until recently tobacco control lacked global leadership and strategic direction and had been severely underfunded. As part of moving towards a more sustainable form of globalisation, a global enabling environment linked to local actions should focus on the following strategies: global information management; development of nationally and locally grounded action; global regulation, legal instruments, and foreign policy; and establishment of strong partnerships with purpose. As the vector of the tobacco epidemic, the tobacco industry's actions fall far outside of the boundaries of global corporate responsibility. Therefore, global and local actions should not provide the tobacco industry with the two things that it needs to ensure its long term profitability: respectability and predictability.

(Tobacco Control 2000;9:206-216)
\end{abstract}

Keywords: globalisation of tobacco marketing

Last year's BBC Reith Lecture series, given by Anthony Giddens of the London School of Economics (LSE), focused on globalisation. Giddens noted that "Globalisation is a complex set of processes, not a single one. And these operate in a contradictory or opposition fashion." Also, "Globalisation, isn't developing in an even handed way, and is by no means wholly benign in its consequences ... many of the most visible cultural expressions of globalisation are American-Coca-Cola, McDonalds." While not explicitly naming Philip Morris or British American Tobacco Company (BATCo), he continues, "some transnational companies sell goods [internationally] that are controlled or banned in the industrial countries" and included high tar and nicotine content cigarettes in this category. ${ }^{1}$ Thus tobacco is at the centre of the contradic- tions inherent in the evolving process of globalisation. It is where the goals of a set of multinationals are clearly in conflict with public health and welfare, and where globalisation of values such as accountability and corporate responsibility are under severe pressure.

Although there is much debate in academic and policy circles about the meaning of globalisation, the principal arguments supporting the idea that globalisation comprises a new epoch in world politics include the following:

- rapid economic transformation in which states are no longer closed units and cannot control their economies;

- electronic communications have fundementally revolutionised our perceptions of the social groups we live and work in;

- a global shared culture is emerging;

- the world is becoming more homogeneous with differences between peoples diminishing;

- time and space seem to be collapsing with, for example, the speed of modern communications and the media;

- a global polity is emerging, which is characterised by transnational social and political movements;

- a cosmopolitan culture is developingpeople are starting to "think globally and act locally";

- a risk culture is emerging with the realisation that many problems are global, and that states cannot deal with these problems on their own. ${ }^{2}$

Parallel trends have been described in a public health context as the "globalisation of public health". ${ }^{3}$ The transnationalisation of marketing and promotion of harmful commodities, such as tobacco, is one important component of globalised public health threats. Moreover, considering that in $1986,61 \%$ of the world's tobacco consumption was in developing countries and by the year 2000 this number is expected to jump to $71 \%{ }^{4}$; that by $2020,70 \%$ of the expected 8.4 million deaths caused by tobacco will be in developing countries $^{5}$; and that at present almost $70 \%$ of tobacco is grown in developing countries, ${ }^{4}$ tobacco control needs to be a higher priority in development programmes.

Most now recognise that globalisation is a double edged sword. This was clearly seen at the World Economic Forum on "Responsible Globality" held in Davos, Switzerland in February 1999. During the forum, tobacco was mentioned as a major threat to world health by Gro Harlem Brundtland, director general of the World Health Organization 
(WHO) (see appendix, note A). Later, during a debate between Martin Broughton, chairman of BATCo, and Derek Yach, WHO project manager for "Tobacco Free Initiative", the sharp division between two worldviews, pro-health and pro-tobacco control, became clear.

This article highlights why the globalisation of tobacco marketing, trade, and influence represents a major threat to world health and to accepted notions of corporate behaviour; indicates how the tobacco industry has targeted the world as its operating unit; and discusses responses to this unprecedented global epidemic.

Globalisation and the tobacco industry

As the vector of the tobacco epidemic, an increasingly globalised tobacco industry is acutely aware of the characteristics of globalisation. The huge tobacco multinationals are attempting to manipulate globalisation trends in their favour. In an increasingly globalised marketplace "mega mergers and acquisitions have dramatically changed the face of the worldwide cigarette industry". ${ }^{6}$ Cigarette companies are looking for greater production volumes: "the more you produce the more profitable you are."

The global shift towards trade liberalisation, facilitated by multilateral trade agreements such as the single package of World Trade Organization (WTO) trade agreements, regional, and bilateral agreements have encouraged the penetration of new markets by tobacco multinationals. Market liberalisation and penetration has been linked to a greater risk of increased tobacco consumption, especially in low and middle income countries. ${ }^{7}$ Directly linked to the business opportunities offered by global trade liberalisation, multinationals such as BATCo are anxiously awaiting further opening of the Chinese market. Martin Broughton recently stated: "I hope that there will be a successful negotiation of China's entry into the World Trade Organization before the commencement of a new round of multilateral trade talks [next year] ... We would hope to improve our market access and secure tariff reductions and I welcome reports that China has offered far-reaching cuts." ${ }^{\prime 8}$ The fact that the opening of markets and the process of globalisation has been linked to increased health risks supports the need for a stronger national regulatory environment for tobacco control and harmonisation of national policies between countries. This approach is permissible under the 1990 General Agreement on Tariffs and Trade Panel Report, Thailand - restrictions on importation of and internal taxes on cigarettes, as long as such norms do not discriminate against foreign commodities in preference for those which are domestically produced. ${ }^{9}$

The tobacco industry's strategies are intimately linked with the idea of international brands. The industry recognises that in many areas "from advertising to quality standards, it is easier to control one brand than many different ones". ${ }^{6}$ The industry looks towards the creation of new "global brands" and a "global smoker" as one way of overcoming markets which have resisted the tobacco industries onslaught:

"[G]lobalisation has its limits. In India, for instance, around 80 per cent of the population uses traditional tobacco products such as bidis or chewing tobacco ... For how long will these markets resist the attraction of global trends? In one or two generations, the sons and grandsons of today's Indians may not want to smoke bidis or chew pan masala ... Global brands are one way to accelerate this process." ${ }^{\prime 6}$

In other words, industry strategists are encouraging the homogenisation of the global tobacco industry and the creation of a new global shared culture enshrined in the concept of a global smoker. The global consolidation of the tobacco industry, a downside of the globalisation process, is an obvious vehicle for promoting the idea of global smokers and their global brands.

\section{THE EXTENT OF THE THREAT}

If the world were a village of 1000 people, it would include 584 Asians; 150 Europeans, of which 55 are from the former Soviet Republics; 124 Africans; 84 Latin Americans; 52 North Americans; and 6 Australians and New Zealanders. In this 1000 person village, 229 adults -173 men and 56 women-smoke. Further, 115 of the smokers are Asian, 28 are European and 28 are African. The tobacco industry would see massive marketing opportunities in the Asian population and among women for its products.

A careful reading of the industry documents released as part of the Minnesota trial reveals the tobacco industry's clear focus on Asia. In 1992, a Rothmans executive stated succinctly that "thinking about Chinese smoking statistics is like trying to think about the limits of space". ${ }^{10}$ In a confidential note from a BATCo tobacco strategy group in September 1994, "it was agreed that China is the top priority in terms of size and potential ... in Japan, the strategy is aggressive organic growth". ${ }^{11}$ In that meeting a "revised, more proactive approach to smoking issues" was presented to be "communicated in clear, credible terms with no time lag around the group. The objectives are to influence opinion and news". ${ }^{11}$ However, Asia is not the only target market or the only population to suffer the consequences of tobacco industry globalisation.

The tobacco industry does not acknowledge that if none of the 229 regular adult smokers in the hypothetical 1000 person global village quit, 114 of them, fully half, will die because of tobacco. Furthermore, the industry has not conceded that environmental smoke kills and harms the health of non-smokers, which is particularly alarming in light of the fact that of the 124 children in the village, almost $40 \%$ are exposed to tobacco. Today, tobacco use kills four million people annually worldwide. This figure will increase to 10 million by about 2030 , by which time $70 \%$ of the deaths will be in developing countries. ${ }^{7}$ 
Members of the tobacco industry continue to deny the addictive properties and the poor health outcomes that are associated with tobacco use. This is in direct contrast to the awareness of the deleterious effects of tobacco use demonstrated by decades of industry documents, over 35 million pages of which were released as a result of the Minnesota law suit. Only a fraction of these documents have been analysed; yet even that fraction indicates a long running deception by the industry as to the extent of their knowledge. As was noted during the opening of the "Seminar on tobacco industry disclosures: implications for public policy", held in Geneva, "through these documents [it is possible to] find information that will add power to the ability of countries all over the world to press for comprehensive tobacco control measures". ${ }^{12}$ The documents show clearly that the industry realised the threats associated with their disclosure; the BATCo documents refer to "a discussion about the destruction of the documents" and the RJ Reynolds (RJR) documents recall systematic efforts to cleanse or "invalidate" its files and documents. ${ }^{13}$

Although the global tobacco industry is actively trying to harness the forces of globalisation in its favour, it is clearly wary about the prospect of litigation becoming a global trend. The Tobacco fournal International recently noted: "One phenomenon that has so far failed to become really global is litigation. While companies in the USA, the world's most important trendsetting nation, are deeply involved with judicial claims against them, this development hasn't found a similar fertile ground anywhere else in the world. The tobacco industry has been sued in countries as different as Panama, the United Kingdom and Israel, but plaintiffs have had only small successes."

What is not revealed in official comments like this one is the industry's use of global networks such as that utilised by Phillip Morris International subsidiaries for routing and storage of particularly sensitive documents. A handwritten document retrieved from Thomas S Osdene, former director of Philip Morris research, describes plans to: “(1) Ship all documents to Cologne . . .; (2) Keep in Cologne; (3) Okay to phone and telex (these will be destroyed) . . .; (5) We will monitor in person every two to three months; (6) If important letters or documents have to be sent, please send to home-I will act on them and destroy." 13 This example of industry deception demonstrates how fraudulent activities themselves can be globalised.

Although a global trend towards litigation has not yet taken place, it is safe to say that since more information has been disclosed about the activities of the tobacco industry "policy makers, programme personnel, and researchers" have focused on the tobacco industry as the "underlying cause" of the tobacco epidemic. ${ }^{14}$
CONTROLLING THE DEBATE

The combination of the tobacco industry's almost US $\$ 400$ billion annual turnover and powerful longstanding linkages to governments and a range of organs of civil society makes progress towards a tobacco free world a difficult process that will take decades and the dedication of millions. Philip Morris' massive investments in marketing over the last 40 years recently resulted in Advertising Age provocatively naming the Marlboro Man the number one advertising icon of the century. As is explained in the accompanying text, "[The Marlboro Man is] the most powerful-and in some quarters, most hated-brand image of the century." ${ }^{15}$ Contrast the powerful Marlboro icon with the humble and well recognised no smoking sign, also in Marlboro red. It aims to improve public health but has much less power to influence the behaviour of millions.

Tobacco control is essentially powerless in the face of tobacco brand control. The tobacco industry controls huge global budgets and legislator's behaviours in many countries, as well as controlling the language of the debate. The contrast between tobacco control and the tobacco industry begs the question: Who controls the global tobacco control movement? This question merits a brief discussion of tobacco industry influence on the budgets and policy of specialised agencies of the United Nations system, in particular WHO and the World Bank, as well as the industry's framing of the ongoing freedom of expression in advertising debate. Additionally, it is useful to examine the tobacco industry's challenge of the scientific evidence on addiction/health effects of tobacco and their developing agricultural lobby. The influence harnessed by the tobacco industry using these mechanisms is planned centrally and extends globally through a complex interlinking network of players.

INFLUENCING THE WHO BUDGET

More than a decade ago INFOTAB, a tobacco industry supported think tank, published "A guide for dealing with anti-tobacco pressure groups". ${ }^{16}$ This guide calls for the establishment of an "early warning system" to detect dangerous signs such as the "presence of a WHO regional office, setting up of a regional workshop of activists, setting up of non-smoker's rights associations, and starting up of an anti's coalition." ${ }^{\prime 16}$ If a pro-tobacco control group is identified, the think tank recommends that the industry "form industry lobby groups and alliances with the core arguments freedom/liberty, attack the credibility of activists; and stress the industry's role in jobs and revenue". ${ }^{16}$

These suggestions from more than 10 years ago were accompanied by the tobacco industry's concerted effort to slow the growth of anti-tobacco programmes. Material from BATCo documents indicates that four years later they were studying WHO's programme budget in detail and commissioning academics to write articles seemingly in their private capacity that questioned WHO spending priorities. For example, Paul Dietrich, 
president and sole member of the Institute for International Health and Development, who was influential in downplaying tobacco in a New York Academy of Sciences publication and Bob Tollison, from the Centre for Study of Public Choice, were paid by BATCo to prepare articles that later appeared in the International Herald Tribune. The core of their argument was that WHO "spending should be concentrated on fighting diseases in third world nations, leaving rich, first world nations to finance their own programs. Hence, WHO funds would go for fighting malaria and cholera, but not go for the campaigns for seat belts or against cigarettes and alcohol". ${ }^{17}$ This theme continues with Dietrich's most recent article in the International Herald Tribune urging a stronger attack on infectious disease. ${ }^{18}$ In reality, if these erroneous ideas continue to be repeated in major global media there is the threat that they will become accepted as fact.

Concern about documentary evidence pointing to a systematic and global effort by the tobacco industry to undermine tobacco control policy and research and development within the United Nations family, and WHO in particular, resulted in Dr Brundtland launching an inquiry into the nature and extent of the undue influence which the tobacco industry has exercised over United Nations organisations, such as WHO. She referred to the decision to launch this inquiry as one which is "in the service of public health".

LOBBYING THE WORLD BANK

The WHO is not the only United Nations specialised agency to come under the scrutiny of the tobacco industry. The World Bank's 1993 World Development Report, Investing in health, called for the Bank to end its support of tobacco production and processing but urged the Bank to "treat the subject with sensitivity and flexibility in some countries which are heavily dependent on tobacco as a source of foreign exchange". ${ }^{19}$ Following publication of the World Development Report, BATCo defined their objective in World Bank (WB)/International Monetary Fund (IMF) lobbying as "influencing the degree of sensitivity and flexibility exercised by the WB/IMF" ${ }^{20}$

DISTORTION OF THE TRUTH ABOUT ADVERTISING The tobacco industry has long maintained that tobacco advertising bans constitute an infringement of commercial speech rights. Thirty years ago, Brown and Williamson proposed to launch an advertisement proclaiming: "The cigarette industry is being maliciously, systematically lynched . . . It's more than cigarettes being challenged here. It's freedom. We will continue to bring to the American people the story of the cigarette and any other legal product based upon truth and taste. We believe that free speech and fair play are both the heritage and promise in our society of free and responsible enterprise." ${ }^{21}$ Today, this message is still being spread by a range of groups that receive large sums of money from the industry. Included in this grouping is the American Civil Liberties Union who accepted nearly $\$ 1$ million from Philip Morris and the International Advertising Association. ${ }^{22}$

The counter argument, which rarely emerges, is simple. Governments limit tobacco companies' product advertisement because it influences the behaviour of children, is deceptive, and leads to addiction. Individuals who are addicted are not "free to choose" and this compromises government's role in fostering individual liberty. Organisations and individuals involved in the pro-tobacco control movement are currently ensuring wider distribution of these counter arguments in countries where legislation is being debated.

CONTINUED QUESTIONING OF THE SCIENTIFIC EVIDENCE ON ADDICTION AND HEALTH EFFECTS OF TOBACCO

In early 1999, the chairman of BATCo, in a letter to the WHO director general, maintained that tobacco was addictive only in the sense in which chocolate was addictive (see appendix, note B). Despite such arguments, his company and other tobacco companies have invested heavily in studying the science of addiction and how best to manipulate nicotine to maintain and increase smoking rates. For example, Claude Teague, assistant director of research at RJR, commented that "in a sense, the tobacco industry may be thought of as being a specialised, highly ritualised and stylised segment of the pharmaceutical industry. Tobacco products, uniquely, contain and deliver nicotine, a potent drug with a variety of physiological effects .. Thus a tobacco product is, in essence, a vehicle for delivery of nicotine, designed to deliver the nicotine in a generally acceptable and attractive form". ${ }^{23}{ }^{24}$ Despite the silence on issues of addiction, a 1980 BATCo document clearly acknowledges that "smoking is addictive" and that "many smokers would like to give up the habit if they could". ${ }^{13}$ Furthermore, tobacco companies also devoted decades of research to studying the alteration of the chemical forms of nicotine to increase the percentage of freebase nicotine delivered to the smoker. Tobacco company documents indicate that this can be achieved by raising the $\mathrm{pH}$ of smoke by the use of additives, most notably, ammonia. ${ }^{13}$

The industry disclosure documents also reveal that US manufacturing defendants did not adequately perform "in-house smoking and health research, including biological research". ${ }^{13}$ Moreover, when RJR's biological research in the 1960s revealed adverse health effects it was closed down: "preliminary results from mouse inhalation tests in the RJR mouse house demonstrated 'a diffuse, marked emphysema throughout the lungs ....."13 There is also evidence to suggest that the failure of the tobacco manufacturers to conduct health research was partly the result of conspiracy. ${ }^{13}$ The Minnesota tobacco litigation case extensively documented how the industry carried out a public relations campaign in order to create doubt about the links between smoking and disease. A 1972 Tobacco Institute memorandum describes a "holding strategy, consisting of: creating doubt about the health 
charge without actually denying it". ${ }^{13}$ This behind the scenes manoeuvring can be contrasted with the industry's deceitful statements on the public level where the industry claimed, inter alia: "We believe the products we make are not injurious to health . . . We always have and always will cooperate with those whose task it is to safeguard the public health."13

In a tobacco strategy review team meeting in February 1992, at which the former BATCo chairman, Sir Patrick Sheeny, and the current chairman, Martin Broughton were present, the reported impact of the development of a nicotine patch on the tobacco industry was discussed. It was concluded that "it does not appear to represent a major threat to the tobacco industry". ${ }^{25}$ With sales increasing, and new products likely, they may well be proved wrong.

DEVELOPING THE AGRICULTURAL LOBBY Last year, Richard Tate, President of the International Tobacco Growers Association (ITGA), expressed his concern that poor farmers in Africa would suffer if the WHO's initiatives were successful (personal written communication with Derek Yach, 2 March 1999). The ITGA, he maintained, is independent of industry and wants a dialogue with WHO (see appendix, note C). This statement appears to be in conflict with the history of the development of the ITGA as discerned from industry documents. In a 1988 INFOTAB document, the following are listed as suggestions to the board members in the pursuit of establishing an agricultural lobby:

- "We need to develop the agriculture lobby.

- We must ensure growers stick to politics and do not seek to use the global organization to gang up on manufacturers.

- The nearest thing to a 'global' organization is the International Flue-Cured Tobacco Growers' Association. It is poorly run . . . but it contains the core of a genuine 'ITGA' - with full geographic spread.

- ITGA might get fully accredited observer status at the FAO.

- INFOTAB should assist in the formation of ITGA . . . with initial funding of US\$400 000

- ITGA would have the clout to combat idiotic crop substitution programmes.

- ITGA could 'front' for our third world lobby activities at WHO." 26

By 1991, the ITGA had spelled out detailed plans concerning its strategies for lobbying ambassadors from key countries to influence WHO policy on tobacco, ensure that the Food and Agriculture Organization (FAO) continues to support tobacco growing, and deliver to the 1992 United Nations Conference on Environment and Development in Rio de Janeiro the message that tobacco's relative importance within the deforestation issue is minimal. ${ }^{27}$ Later, in 1993, BATCo coordinated concerted activity in response to the First All Africa Conference on Tobacco Control convened in Harare, Zimbabwe. BATCo and ITGA documents state: "This conference ... is the first of its type and is likely to be the forerunner to similar attacks on the industry." ${ }^{28}$ BATCo funded a media briefing seminar in South Africa a month before the All Africa Conference on Tobacco Control at a cost of US $\$ 90000$ which was approximately $\$ 25000$ more than was spent on the conference itself. ${ }^{28}$ A BATCo sponsored media training workshop in Harare was also held which Richard Tate, who was not yet an official with ITGA, attended.

The importance of the conference to the ITGA is clear from the contents of a letter from the Agro-tobacco Services to the chairman of ITGA before the meeting. This correspondence states: "As part of our attempt to upstage the conference, the opportunity of launching the ITGA's latest publication in the preceding week was too good to be missed. As you probably know, there will be significant participation by ITGA at the Tobacco Control Conference-a notable achievement for growers and in no small measure due to the influence of the ZTA [Zimbabwe Tobacco Association] with Zimbabwe's Minister of Health." ${ }^{29}$

After the conference, Phillip Morris wrote to congratulate BATCo on the meeting in Zimbabwe and suggested a follow up working session in Harare to discuss the lessons learned from their intervention and participation in the conference. ${ }^{30}$ This communication listed the following items, among others, for inclusion on a tentative agenda:

- "Countering the Harare conference.

- Viewpoints on ANC [African National Congress] commitment to fight smoking and possibilities of a constructive dialogue.

- Possibilities to balance off the anti-smoking policies of the World Bank."

Dr ND Zuma, who was not yet the South African Health Minister, gave a strong and clear indication of ANC support for tough measures against tobacco in the opening session, which she has since implemented (see appendix, note D).

Today, firm evidence from the World Bank, supported by FAO, USAID, and others indicates that supply side approaches to tobacco control are not warranted. ${ }^{7}$ The impact of declining demand will be gradual and extend over many decades. With 1.1 billion smokers today, a figure projected to grow by almost $40-50 \%$ if current policies continue, establishing a goal of an 800 million to 1 billion smoker market by the late 2020 s seems a realistic target for global tobacco control. This is still an enormous market. While it is politically prudent to identify alternative livelihoods for tobacco farmers, one should not assume these would be in agriculture.

ITGA is no different than other front groups set up by industry to block public health policies; as such, it should be disbanded on the same grounds as the Council for Tobacco Research recently was, as an outcome of the Minnesota trial. In this respect, the focus of tobacco control programmes should be to disseminate to agriculture, finance, and trade ministers empirical evidence on the economics 
of tobacco control, as well as the reasons behind the manufacturers desire for ITGA to "front" for them while they do little to support farmers' long term concerns.

\section{Towards a heightened global response:} WHO's new leadership

In contrast to the size of the challenge, global tobacco control has, until recently, lacked sustained global leadership, been severely underfunded, and wanted for strategic direction. Outstanding individuals have emerged on all continents who have tried against severe odds to build broad based institutional support for action, but until now their voices have been drowned in a pool of tobacco money.

The WHO director general's leadership and support for the Tobacco Free Initiative (TFI), as one of three central cabinet projects, provides an opportunity for real global action against tobacco. The key messages of TFI are simple:

- tobacco kills users when used as the manufacturers recommend;

- tobacco kills and harms non-users-these include unborn children and non-smoking spouses;

- tobacco promotion and use is unsound economics;

- policies and interventions are already available to reverse the trends;

- global strategies complement and reinforce national action.

Four priority actions for TFI are emphasised:

- global information management;

- development of nationally and locally grounded action;

- involvement in global regulation, legal instruments, and foreign policy;

- establishing strong partnerships with purpose.

GLOBAL INFORMATION MANAGEMENT

In his latest book, Bill Gates comments that "how you gather, manage and use information will determine whether you win or lose". ${ }^{31}$ At the beginning of a new millennium, the world is entering an era in which, to update Marshall McLuhan, messages are independent of their medium. Video, internet, newspaper, compact disc, and mobile phone all share the use of digital language. This language is portable across many platforms and is not hampered by geography. It creates unprecedented opportunities for actions whose success requires information rich interventions - and this is the case with tobacco control. In public health, and specifically in tobacco control, determining success, or "winning" in Gates' terminology, is measured by the magnitude of prevention of premature death.

The major tobacco control intervention is information. This includes information about health effects, the negative economic impact of tobacco, the benefits of quitting, what policies work and the structure and functioning of the tobacco industry. Making this body of material available on time to key groups will make a dif- ference to the epidemic. There exists a growing ability through the internet to interact simultaneously with key policy makers, academics, and non-governmental organisations (NGOs) in all countries. A threat from an industry action in one country is shared globally, and best practices appropriate to the country can be developed electronically.

In 1992, when GlobaLink, the current major platform that now links over 1200 tobacco control programmes worldwide, was being developed, an American spokesman for the Tobacco Institute commented in a letter to their South African affiliate: "Through a worldwide computer network established by the Washington DC based Advocacy Institute, anti-tobacco activists now are able to transmit media advisories, reactions and proposed sound bites on virtually any smoking related issue to colleagues in other countries, and to the press. I have told our members that I believe that this expanding, sophisticated infrastructure is probably one of the greatest challenges our industry has confronted. ${ }^{\prime 32}$ This network has demonstrated the power of modern information technologies to close the gap between global and local concerns.

Serious expansion of the reach, content, and uses of this platform is now underway. TFI, in conjunction with the Centers for Disease Control and Prevention, the World Bank, and the International Union Against Cancer (UICC), have defined a strategy to develop a global tobacco surveillance system. This new system will provide information on patterns of prevalence, trends in tobacco related morbidity and mortality, policy and programme interventions, and tobacco industry analysis. The goal is to allow the truth to emerge wherever and whenever the tobacco industry is active. While information exchange is vital, for the long-term and for true, sustained action, the major benefit of the internet is the improved connectivity of people.

Giddens comments in the BBC Reith series that the "communication revolution has produced more active citizens than existed before". ${ }^{1}$ Not only are citizens more active nationally, but as communities with shared concerns become connected across the globe, the opportunities for mass based action against the abuses of the tobacco industry are increasing.

Many citizens in countries with progressive tobacco control policies are outraged about the lack of coherence between domestic tobacco control and their countries' trade policies. By connecting groups in countries where tobacco marketing and exports originate with the target consuming countries via the creation of a virtual community, this outrage can be turned into pressure for tobacco control policy in real communities. This probably played a role in the USA where embassies are now required to support tobacco control and not expansion of the tobacco industry. The recent Doggett Amendment which prohibits US tobacco product promotion abroad is an important sign of progress being made by the US Departments of Commerce, State, and Justice. 
It sends a powerful message to all US missions around the world about the need to consider the public health implications of tobacco control. ${ }^{33}$

The recent UK White Paper on tobacco-"Smoking Kills"-also indicates an intent to move in a similar direction. ${ }^{34}$ As one of the international policy recommendations for posts overseas, the UK White Paper states: "in keeping with the current practice of ministers and officials not becoming involved in the advertising or promotion of tobacco products at home, guidelines will shortly be issued to representatives in our diplomatic posts instructing them to be scrupulous to ensure that they follow suit overseas, taking into account local circumstances." ${ }^{34}$ Accordingly, the Secretary of State for Foreign and Commonwealth Affairs of the UK has issued the following guidelines to overseas posts: "Posts must no longer directly promote products containing tobacco . . . especially where this might be misconstrued as some form of government endorsement or approval of them; posts should not inter alia be associated with the promotion of the tobacco industry; posts should not support activities designed specifically to encourage smoking." These guidelines took effect starting on 1 June 1999..$^{35}$

NATIONALLY AND LOCALLY GROUNDED ACTION The strength of any global policy depends upon the degree to which it is firmly grounded in communities and countries. During the Tobacco Free Initiative's initial two years of work it received demand for stronger action from countries. Often these demands come from governments who felt powerless in the face of tobacco industry pressure to do what they know should be done.

Dr Brundtland's powerful advocacy is acting as an umbrella under which countries feel safe to speak out clearly. New opportunities have been created for senior legislators to share experiences and to hear that their problems are not unique. An example of this was a meeting in Washington, DC, in March 1999, which brought together elected officials and several ministers of health to discuss how to prevent tobacco use among children and youth. What emerged was a stronger sense of global solidarity concerning the need to share stories about successes and failures and the need for joint action between countries in diverse regions and at differing levels of development.

However, national action is not sufficient. In the age of immediate, accessible communication, cross cultural and international communication and unification is possible. Communities with shared values are now able to work together more easily then before as result of information technologies. Thus, we have patients seeking treatment for their tobacco dependence being supported remotely through the internet and religious groups exchanging views on how to strengthen tobacco control within their communities. Many geographically based health promotion entities such as schools and cities have embraced tobacco control as part of health promotion in schools or healthy cities programs. Global networks of local groups allow for exciting local-global synergies.

GLOBAL REGULATION, LEGAL INSTRUMENTS, AND FOREIGN POLICY

A wide range of international instruments is being pursued to strengthen tobacco control. These recognise that national tobacco control laws are powerless to control transnational aspects of tobacco control such as marketing and promotion, smuggling, regulation, and product design.

In 1993 Philip Morris records from an internal meeting described the tobacco industry approach to "a global regulatory network". ${ }^{36}$ In this network, the six major US based companies and their legal counsel, Covington and Burling, would develop a common approach to countering legislative and regulatory strategies being developed by WHO and a range of $\mathrm{NGOs.}$

However, WHO and its partners in tobacco control are currently addressing and will steadfastly continue to address the transnational aspects of tobacco control. As the WHO director general recently said: "The tobacco habit is extensively communicated. It is communicated through the media, the entertainment industry, and most directly through the marketing and promotion of specific products. Global trade in tobacco has increased markedly over the last few years. Direct foreign investment by multinationals in developing countries has also increased. New joint ventures are announced every few months between multinationals based in a few developed countries and the governments of emerging markets. We need an international response to an international problem."12

The Framework Convention on Tobacco Control (FCTC) is a critical component of WHO's response to these problems. In May 1999, the World Health Assembly, the governing body of the WHO, unanimously adopted resolution WHA52.18 calling for work to begin on the FCTC. This is the first time in WHO's 50 year history that it has exercised its treaty making powers mandated in article XIX of the WHO Constitution. The size of the public health problem the world faces from tobacco use demands such a response.

Tobacco industry opposition to all forms of legislation and regulation at national and especially international levels continues overtly and covertly. If the recently released documents predict future action, it is clear that the tobacco industry will use surrogate experts to attempt to delay the FCTC process, lobby countries to raise concerns about immediate job losses, and mount media campaigns against any effective measures proposed. However, early support for FCTC has been broad based and enthusiastic. During the debate on the FCTC resolution at this year's World Health Assembly, a record number of 50 states, five NGOs, and the European Union took the floor to pledge financial and political support for the convention. This list included the five permanent members of 
the United Nations Security Council, major tobacco growers and exporters, as well as several countries in the developing and developed world which face the brunt of the tobacco industry's marketing and promotion pitch. The fact that countries heavily dependent on agricultural production spoke out in favour of the FCTC resolution is particularly noteworthy. In this regard, Malawi noted that the country was far from being a major beneficiary of its tobacco production, even though multinational companies continued to make profits year on year; stagnating raw tobacco prices has led to moves towards agricultural diversification. Moreover, Brazil, a major tobacco producing country, emphasised that tobacco control was not against farmers, but for the interests of the population as a whole. Therefore, Brazil recommended that a joint approach to the tobacco problem was needed, and would include studies and financing of alternative crops and activities. ${ }^{37}$

The first meeting of the working group on the FCTC was held in Geneva, October 1999. This intergovernmental technical body has set the scientific foundation for the formal negotiations, which are expected to commence in October 2000. The first working group was attended by participants from a wide range of sectors and included representatives from 114 member states, the Holy See, Palestine, the European Community, 10 United Nations organisations, four other intergovernmental organizations, and 31 NGOs. Approximately $92 \%$ of the world's population was represented by the member states in attendance. The second working group, attended by 142 member states, was held in Geneva in March 2000, and considered the further elaboration of elements of the framework convention and prepared a final report which was submitted to the 53rd World Health Assembly, May 2000.

Multilateral action is not enough, though. Countries need to ensure that their development and foreign policies are supportive of tobacco control. The US embassy policy, as well as the recently issued guidelines to UK overseas posts, are both strong initial showings. The UK White Paper also states: "We will ensure that development assistance funds are not used for any purpose which identifiably supports the tobacco sector in aid recipient countries. At the same time, funding in these countries can be provided to help reduce tobacco dependence as well as to help farmers dependent on tobacco to diversify into alternative activities." ${ }^{34}$ Similar statements have been made recently by other countries including the USA. It is hoped that such statements of intent will be backed with action and funds.

In the USA, litigation has brought about a shift in the opportunities for global tobacco control. As mentioned, the industry documents now available were largely a product of the Minnesota based law suit. Moreover, the settlement between the tobacco industry and 46 states finalised in November of 1998 has had several international impacts already. For example, in March 1999, BAT Plc announced that its pretax profits had dropped by $16 \%$ because of two main factors: the Asian economic turmoil and the US litigation costs. In March 1999 BATCo chairman, Martin Broughton, commented: "While it was a high price to pay, it has lifted a tremendous burden from the industry. The legal situation is no longer life threatening." 38 However, this statement may prove to be premature. At last count some type of litigation was underway in at least 15 countries, ranging from personal class action litigation in Australia to health care recovery in Canada to public interest petitions in India.

Last April, the US federal government announced its plan to call on the successful Minnesota law team to prepare for a federal civil case against the tobacco industry. In addition, other litigation against the tobacco industry by non-governmental plaintiffs continues in the USA. The globalisation of successful litigation approaches supported by evidence of tobacco industry complicity in blocking tobacco control in developing countries could well lead to further declines in their profits. Several new approaches to global tobacco control are starting to converge, including better surveillance and brand specific prevalence rates among children worldwide. These tools may become means of verifying compliance with a future convention. The onus of accountability and the burden of penalties would move from governments to the tobacco industry.

News in recent months has been particularly filled with tobacco smuggling stories. In December 1999, the Canadian government filed a lawsuit under the Racketeer Influenced and Corrupt Organisations Act (otherwise known as RICO) in the US federal court. The government of Canada has claimed that various RJ Reynolds tobacco companies and others defrauded the Canadian people by conspiring to smuggle tobacco into Canada. Further, in the UK, it was revealed that BAT may have been implicated in some smuggling activities in Asia and Latin America. In an unprecedented move the chief executive officer of BATCo launched an internal inquiry to investigate this issue. Also, on 7 April 2000, in a landmark case a Miami jury awarded $\$ 12.7$ million in compensatory damages to three smokers with cancer. The same jury that awarded the compensatory damages will hear testimony on potential punitive damages in a class action lawsuit involving an estimated 500000 sick smokers. This case has the potential to cripple seriously the tobacco industry.

PARTNERSHIPS WITH PURPOSE

The globalisation of risk beyond national borders means that individual governments cannot meet the challenges of tobacco control alone. A strong network of partners, each with its own identified unique and complementary roles in tobacco control, is emerging. When the United Nations coordination mechanism conference on trade and development (UNCTAD) was announced as the United Nations focal point for tobacco issues in 1993, 
the tobacco industry reacted strongly. An internal BATCo statement contained the following quote: "The most significant development during the past 12 months, and one which presents us with the greatest challenge, is the decision of the United Nations Economic and Social Council to establish a 'focal point' within the UN system to facilitate a wide ranging debate on tobacco related issues ... We can therefore expect a number of UN agencies to get into the act. It is to be hoped that they do not bring to their participation any prejudicial anti-tobacco sentiments."(29) The focal point was poorly financed and ineffective.

In April 1999 the United Nation's administrative committee on coordination/ organisational committee, at the request of the WHO director general and with support of UN secretary general Kofi Annan, agreed that an ad hoc inter-agency task force on tobacco control (under WHO's leadership) would replace the former UN focal point. Furthermore, a formal resolution of the United Nations Economic and Social Council, which was adopted in July 1999, endorsed the new task force and requested the UN secretary general to report to the Economic and Social Council at its substantive session of 2000 on progress made by the task force on the implementation of multisectoral collaboration on tobacco or health, with particular emphasis on the development of appropriate strategies to address the social and economic implications of the impact of tobacco or health initiatives. Fourteen United Nations organisations, the World Bank, the International Monetary Fund, and the World Trade Organization, are participating in the task force's ongoing work. The task force, which has already met twice, is significantly expanding the horizons for multisectoral collaboration across the United Nations system.

Outside the UN, a working arrangement is evolving with the pharmaceutical industry, through the trade bodies the International Federation of Pharmaceutical Manufacturers and the World Self Medication Industry. This partnership enhanced the global campaign promoting "World No Tobacco Day 1999", resulting in a wider scope of activities, ranging from support for a consultation on tobacco cessation to the promotion of partnership with both WHO and health professionals. During World No Tobacco Day several countries in Africa mobilised governments, NGOs, and media, demonstrating genuine commitment to fight against tobacco. Countries mobilised several organisations including ministries of health, NGOs, research institutions, police forces, schools, universities, church organisations, and even media associations. ${ }^{39}$ It is crucial to broaden the range of partners to include the information technology, entertainment, media and sports industries. In this respect, World No Tobacco Day 2000 has a focus on the entertainment industry with a view to highlighting the promotion of advertising of tobacco in films, music, and sports. Tobacco is a communicated disease- communicated through various media, but most importantly the entertainment industry. In summary, the goal must be to have a solid core of private sector partners who understand that their products and services are fundamentally different from those of the tobacco industry. Tobacco products are inherently dangerous. No amount of denial can hide this harsh fact.

The role of a vibrant NGO sector that is able to mobilise citizens and governments to act is essential to the success of the tobacco control movement. In May 1999, before the World Health Assembly, several major NGOs met to define-in areas such as women's roles in resisting the tobacco industry, health care and cessation, and human rights and consumer protection-how best to organise for more effective work at local and global levels. ${ }^{40}$ This is already happening with a spectrum of health professional bodies including the World Medical Association, the International Council of Nurses, and the World Federation of Public Health Associations, as well as national NGOs, such as Action on Smoking and Health (ASH), and consumer groups. Each of the partners mentioned, UN bodies, multinationals, and NGOs has global mandates and simultaneously draw their strength from and are based in communities and countries. Thus, through the participation of a multitude of partners, WHO is able to work globally and locally on tobacco control.

\section{Towards a sustainable globalisation?}

Increasingly, national social policies are being affected by transnational forces. With the advent of global markets "social policy activities traditionally analysed within and undertaken within one country now take on a supranational and transnational character". Questions of how to create a socially regulated global capitalism, rather than an anarchic unregulated system, are becoming part of the mainstream global social policy debate. ${ }^{41}$ In this regard, social improvements, for example in public health, should be seen as a means of forging a sustainable globalisation: health improvements have been increasingly linked to positive economic effects, ${ }^{42}$ and the crucial link between health and human capital formation has become an important area of recent health policy research. ${ }^{19}$

The emergence of transboundary issues such the tobacco epidemic call for a new consciousness which will focus on a more sustainable form of globalisation. Such a shift of global public opinion is evident in recent attitude shifts towards the tobacco industry: "Today, however, we are witnessing the early signs of a shift in public consciousness. Such corporate excesses as Big Tobacco's manipulation of nicotine levels to increase addiction . . have disturbed a growing segment of the population." 43

In the evolution of social policies to address the negative externalities of globalisation, public health problems need to be considered as part of widening the globalisation paradigm/ debate. An important part of these evolving 
global norms needs to include "global social responsibility in the private sector". ${ }^{44}$ In this regard, the emergence of corporate responsibility should minimise the negative impacts and maximise the positive opportunities "in core business activities, via social investment activities and engagement in public policy". ${ }^{45}$ Clearly the tobacco industry's strategies/tactics are at odds with the norms of social and corporate responsibility. The Minnesota industry documents clearly show the extent of the tobacco industry's fraudulent activities regarding "what the industry knew-that smoking causes cancer; when the industry knew it-in the 1950s; and what the industry did about it-systematic denial and cover up". ${ }^{13}$ Moreover, recent evidence reported by Ong and Glantz documents how Phillip Morris mounted an "inter-industry strategy" designed to undermine the International Agency for Research on Cancer's (IARC) study on passive smoking, and demonstrates the extent to which the tobacco industry will go to shape media and public opinion. ${ }^{46}$

The tobacco industry's unethical business practices, which have been aimed, inter alia, at deceiving the public about the extent to which tobacco harms people's health, contravene widely accepted ethical considerations. For instance, the industry's tactics are at odds with Shue's six criteria for classifying harms that may not be imposed without the consent of those who will be adversely affected by them. According to Shue's criteria, prohibited harms are those that are the effect from a decision

\section{Appendix}

Point A-Dr Brundtland, in discussing the global burden of disease, noted: "By 2020 the burden of disease due to tobacco is expected to outweigh that caused by any single disease. From its 1990 level of being responsible for $2.6 \%$ of all disease burden worldwide, tobacco is expected to increase its share to close to $10 \% .{ }^{.48}$

Point B-Mr Broughton's full statement was as follows: "On the matter of addiction, there are several definitions in use: under some, smoking, as well as coffee drinking and also chocolate eating, is addictive. While stopping smoking can be difficult for some, we do not consider that there is anything in cigarette smoke that removes the ability of someone to quit, as evidenced by the millions who have."

Point C-This sentiment is echoed in the recently released ITGA documents wherein ITGA's independence from the normal commercial activities of the tobacco industry is emphasised. ${ }^{49}$

Point D-As part of the reorganisation of the South African government following the national elections held on 2 June 1999, Dr Zuma shifted her cabinet portfolio in the South African government from Minister of Health to Minister of Foreign Affairs on 17 June 1999. which (1) may lead to bodily damage, (2) is serious, (3) is irreversible, in circumstances in which the damage is also (4) unavoidably undetectable to the person actually suffering it, (5) is unavoidably unpredictable for the people who may potentially suffer it, and (6) is very likely to occur. ${ }^{47}$

Therefore, as part of moving towards a more palatable form of globalisation, the public should not give the tobacco industry the two things it needs above all to ensure its long term profitability: respectability and predictability. Ongoing community action, a variety of legislative and litigation strategies, and multi-institutional approaches to tobacco control will ensure continued unpredictability for the tobacco industry provided that all are part of a broadly based comprehensive approach spread over years. The analysis of tobacco industry documents and their wide dissemination, along with the epidemiological and economic evidence about the true impact of tobacco, will prevent the tobacco industry from gaining respectability. These actions, simultaneously local and global, could halt and eventually reverse trends currently underway.

This paper is a revised version of a paper originally published on the WHO's Tobacco Free Initiative website

1 Giddens A. Globalisation. Lecture One of the 1999 BBC Reith Lecture series 1999. Published online at news.bbc.co.uk/hi/ Lecture series 1999. Published online at news.bbc.c
english/static/events/reith_99/week1/week1.htm

2 Smith S, Baylis, J. Introduction: globalization-myth or reality? In: Baylis J, Smith S, eds. The globalization of world politics: an introduction to international relations. Oxford: Oxford University Press, 1997

3 Yach D, Bettcher DW. The globalisation of public health I: threats and opportunities. Am $\mathcal{f}$ Public Health 1998; 88:735-8.

4 FAO (Food and Agriculture Organization) cited in MacKay J, Crofton, J. Tobacco and the developing world. In: Doll R, Crofton J, eds. Tobacco and health. London: Royal Society of Medicine Press, 1996:206-21.

5 Murray C, Lopez A. The global burden of disease: a comprehensive assessment of mortality and disability from disease, injuries, and risk factors in 1990 and projected to 2020. Boston: Harvard University Press, 1996.

6 Crescenti MG. The new tobacco world. Tobacco fournal Crescenti MG. The new
International 1998;3:51.

7 World Bank. Curbing the epidemic: governments and the economics of tobacco control. Development in Practice economics of tobacco control. Development
series. Washington DC: The World Bank, 1999.

8 Broughton MF. Opening speech. British American Tobacco Annual General Meeting, April 19, 1999:5.

9 World Trade Organization. Analytical index: guide to GATT law and practice (volume 1). Geneva: The World Trade Organization, 1995.

10 Fletcher R, Rothman's Regional Public Affairs Manager, quoted in Ibison D. Rothman's Joint Deal Opens Heavenly Gates. Window Magazine 1992;4.

11 Barton HC. Internal report of the Tobacco Strategy Group, BAT Industries document. September 7, 1994:202201212216 (internally numbered $1-5$ )

12 Brundtland G. Opening speech. Seminar on tobacco industry disclosures: implications for public policy. Geneva, Switzerland, October 20,1998.

13 Ciresi MV, Walburn RB, Sutton TD. Decades of deceit: document discovery in the Minnesota tobacco litigation. William Mitchel Law Review 1999;25:478-564.

14 Cohen JE, Ashley MJ, Ferrence R, et al. Institutional addiction to tobacco. Tobacco Control 1999;8:70-4.

15 Advertising Age. Top advertising icons. In: Klein D, Donaton S, eds. The advertising century. Published online at www.adage.com/century, 1999

16 INFOTAB. A guide for dealing with anti-tobacco pressure groups. Infotab document, October 1999

17 Tollison R, Wagner R. World Health and the World Health Organization. BATCo document June 23, 1993:500899074.

18 Deitrich P. Count the cost of infectious disease: financing the fight against illness has consequences for investors. International Herald Tribune Money Section. Weekend edition April 3-4 1999;14.

19 World Bank. Investing in health. World development report. Washington DC: The World Bank, 1993.

20 Brady BJ. The World Bank and International Monetary Fund: impact on tobacco policies. BATCo document July 26, 1993:502586979.

21 Post-Keyes-Gardener, Inc. Who's Next? Campaign. Project Truth, proposed advertisement text prepared for Brown \& Williamson. October 171969 
22 Health Letter. The ACLU's Tobacco Addiction. Wolfe SM, ed. Health Letter 1998;14:10-12.

23 RJ. Health Letter 1998;14:10-12. RJ Reynolds. Internal document citing Claude T
Reynolds document 1972;ID number 500915684.

24 RJ Reynolds. Internal document citing Claude Teague. Rf Reynolds document 1983;ID number 511223466.

25 British American Tobacco Company. Tobacco strategy review team meeting minutes. BATCo document May 29 1992:202227112-120 (internally numbered 1-9)

26 Bloxcidge J. International Tobacco Growers' Association. INFOTAB document file number BA0143, box number DEP0304, October 11, 1988:5025555416.

27 British American Tobacco Company. The Agro-Tobacco Program. BATCo document file number BA0143, box number DEP0304, 1991:502555358-363.

28 Brady BJ. Appendix II: action points and recommendations. BATCo document, June 30, 1993:300565566.

29 Oldman M. Communication with Mr HBJ Ntaba, chairman of the International Tobacco Growers' Association. of the International Tobacco Growers Association. BATCo document File number 0143, box

30 Carlson S. Third World Farmer Mobilisation: Communication between $\mathrm{Mr}$ Carlson, director of corporate affairs for Philip Morris and multiple colleagues. BATCo document File number BA0143, box number DEP0304, Novembe 23, 1993:502555318-319.

31 Gates B.Business@ the speed of thought: using a digital nervous system. Los Angeles: Warner Books, 1999.

32 Chicoti S. Communication between $\mathrm{Mr}$ Chicote and $\mathrm{Mr}$ John Groenewald of the Tobacco Institute of South Africa. BATCo document December 17, 1992:304055100.

33 Bloom JL. International interests in US tobacco legislation. Health Science Analysis Project 1998;3:4-8.

34 Anon. Smoking Kills: a White Paper on tobacco. Presented to Parliament by the Secretary of State for Health, and the Secretaries of State for Scotland, Wales and Northe and the land by Command of Her Majesty, December 1998.

35 Hansard. Column 333. Parliamentary answer May 18, 1999.

36 Philip Morris. Global regulatory network: internal report/

presentation. Philip Morris document 1993:20255998799920.
37 Fifty-second World Health Assembly. Tobacco free initiative. Summary Record of the Sixth Meeting of Committee A 1999:19-20.

38 Broughton MF. Quoted in Beck E. BAT's net falls on Asia, settlement costs. Wall Street fournal Europe Corporate News March 10, 1999.

39 Letoré D. Project evaluation report. World No Tobacco Day report. Geneva: World Health Organization, June 1999.

40 International Non-Governmental Coalition Against Tobacco. Together against tobacco: working group reports.
Publication of the INGCAT International NGO Mobilisation Meeting 1999; Geneva, May 15-16.

41 Deacon R, Hulse M, Stubbs P. Global social policy: international organizations and the future of welfare. London: SAGE Publications, 1997.

42 Strauss J, Thomas D. Health, nutrition, and economic development. Fournal of Economic Literature 1998;36:766 817.

43 Matthiessen P. Global corporate power-resist if you can. Financial Times (UK edition). Life/Management Section, May 29; 1999:9.

44 Bettcher DW, Yach D. The globalization of public health ethics? Millennium: Fournal of International Studies 1998; 27:469-96.

45 Davies R. Quoted in Pyke A. Mission possible. Financial Times (UK edition). May 20; 1998.

46 Ong EK, Glantz SA. Tobacco industry efforts subverting International Agency for Research on Cancer's secondhand smoke study. Lancet 2000;355:1253-9.

47 Shue H. Exporting hazards. In: Peter G, Shue B, Shue H, eds. Boundaries: national autonomy and its limits. Totawa, New Jersey: Rowman and Littlefield, 1973.

48 Brundtland, G. Health for the 21st Century. Speech given at the World Economics Forum, Davos, Switzerland, January 30,1999 .

49 Walder D, Chief Executive of ITGA. Communication with G Pedlow, Information Services Manager, BATCo, Ltd. BATCo document File number BA0143, box number DEP0304, May 14, 1990;502555396-502555399.

\section{FOR TOBACCO BIBLIOPHILES}

For $£ 475$ ( $\$ 758$ ) you can be the proud owner of a first edition of Wilhelm Anton Plaz's De Tobacco Sternutatorio (Vom Schnupff-Taback), published in Leipzig in 1727, an anti-tobacco tract against smoking and brain corroding snuff taking. Snuff, Plaz argued, generated "verminium in cerebo", which all Tobacco Control readers will recognise as "worms in the brain". In Plaz's Germany, the use of tobacco was prohibited and the death penalty prescribed. Worse, smoking was even used as a term of abuse against the French. Enquiries to Pickering and Chatto, antiquarian booksellers rarebooks@pickering-chatto.com or 36 St George St, London W1R 9FA, UK. 